\title{
Perspektywa efektywności w resocjalizacji
}

The Perspective of Effectiveness in Resocialization

\begin{abstract}
ABSTRAKT
Weryfikacja podejmowanych działań jest najistotniejszym etapem procesu zmian. Dzieje się tak również w procesie resocjalizacji, którego celem jest powrót resocjalizowanej jednostki do społeczeństwa oraz uzyskanie takich zmian w jej zachowaniu, aby przestrzegała ona obowiqzujacych w nim zasad i norm oraz właściwie wypełniała przypisane jej role społeczne. Taka perspektywa zakłada szereg systemowych oraz zindywidualizowanych działań zmierzajacych do wyposażenia osoby resocjalizowanej w umiejętność autostymulacji do samorozwoju oraz rozwiqzywania sytuacji problemowych innowacyinie i odmiennie od dotychczasowych sposobów. Niniejszy artykuł jest próba prezentacji bogatego dorobku opracowań oraz różnorodności podejmowanych perspektyw badawczych efektywności, która od lat stanowi przedmiot interdyscyplinarnego zainteresowania, mobilizując pedagogów do poszukiwania kryteriów ustalania jej poziomu, determinantów oraz wyjaśniania znaczenia samego pojęcia.
\end{abstract}

SLOWA KLUCZOWE resocjalizacja, adaptacja społeczna, recydywa, niedostosowanie społeczne, efektywność

\section{KEYWORDS}

resocialization, social adaptation, recidivism, social maladjustment, effectiveness

SPI Vol. 21, 2018/1

ISSN 2450-5358

e-ISSN 2450-5366 DOI: 10.12775/SPI.2018.1.004

Nadestano: 14.01.2018

Zaakceptowano: 6.03.2018

Artykuły i rozprawy 


\section{ABSTRACT}

Verification of activities undertaken is the most significant phase of the process of change. This is also applicable to the resocialization process, aimed at returning a resocialized individual to society and changing the individual's behavior in a way to make the person observe social norms and regulations and correctly fulfill one's social role. Such a perspective assumes the use of numerous systemic and individualized activities aimed at equipping a resocialized person with the ability to stimulate self-development and solve problematic situations in an innovative way. The following article is an attempt to present the richness of a prolific scientific study on the topic of effectiveness, which has been an object of interdisciplinary interests for years, mobilizing scholars to search for criteria that could be used to determine the level of effectiveness, its determining factors and clarify the meaning of the term itself.

\section{Wprowadzenie}

Niezależnie od dominujących w różnych okresach rozwoju prawa karnego teorii karania, teoretykom i praktykom od początku upowszechnienia się kary pozbawienia wolności bliska była idea dążenia do zmiany jednostki niedostosowanej w użytecznego członka społeczeństwa ${ }^{1}$. Na określenie tego procesu w polskiej literaturze pedagogicznej, kryminologicznej i penitencjarnej przyjęło się używanie terminu „resocjalizacja”.

Termin ten w kontekście poprawy jednostki niedostosowanej społecznie pojawił się w literaturze na przełomie XIX i XX wieku wraz z przenikaniem do nauk prawnych nurtu pozytywistycznego. W rodzimej literaturze przedmiotu upowszechnił się on dopiero w latach sześćdziesiątych ${ }^{2}$. Podobna sytuacja miała miejsce w piśmiennictwie angloamerykańskim, gdzie określenia rehabilitative

1 H. Machel, Więzienie jako instytucja karna i resocjalizacyjna, Gdańsk 2003, s. 20-25.

2 Zob. C. Czapów, S. Jedlewski, Pedagogika resocjalizacyjna, Warszawa 1971. 
ideal użył po raz pierwszy Francis Allen w 1959 roku $^{3}$. W jego miejsce używano także określeń: rehabilitation, correction oraz treat$m e n t^{4}$. W aspekcie jednostkowym resocjalizacja wywodzi się od pojęcia „socjalizacja” i najczęściej rozumiana jest jako „wtórne uspołecznienie, czyli uwewnętrznienie w jednostce wartości i norm społecznie akceptowanych" . Proces ten polega na przyswojeniu przez jednostkę niedostosowaną społecznie akceptowanych sposobów realizacji własnych potrzeb oraz przyjętych w danej społeczności norm i standardów postępowania ${ }^{6}$. Resocjalizacja jest więc procesem zmian, które mają się dokonać przede wszystkim w obszarze zachowania i osobowości człowieka ${ }^{7}$, a jej podstawowym celem jest zlikwidowanie lub redukcja przejawów niedostosowania społecznego poddawanych jej jednostek ${ }^{8}$. W tak ogólnie określonym celu resocjalizacji wyodrębnia się dwa cele, różnicując je w zakresie stopnia efektywności. Są nimi: cel minimum i cel maksimum. Cel minimum to osiągnięcie takiego stanu osobowości jednostki niedostosowanej społecznie, który umożliwi jej funkcjonowanie w sposób zgodny z normami prawnymi w społeczeństwie po zwolnieniu z zakładu karnego. Zabezpiecza więc przed recydywą i pozwala na wydostanie się z obszaru stygmatyzacji, odpowiedzialnego często za powrót do przestępstwa. Celem maksimum jest natomiast taki stan osobowości, który umożliwi danej osobie funkcjonowanie w społeczeństwie nie tylko w sposób nienaruszający norm prawnych, ale także w sposób respektujący wiele istotnych i ważnych dla życia społecznego norm moralnych. Osiągnięcie go chroni nie tylko przed kolejnym konfliktem z prawem, ale też przed konfliktem z ogólnie obowiązującymi czy uznanymi normami. Tylko osiągnięcie celu maksimum

3 M. Sztuka, Anachronizm i aktualność. Idea resocjalizacji w sporze o nowoczesność, Kraków 2013, s. 86.

4 Zob. K. Pospiszyl, Resocjalizacja nieletnich. Doświadczenia i koncepcje, Warszawa 1990.

5 B. Waligóra, Warunki i instrumenty resocjalizacji osób pozbawionych wolności, w: Spory wokót reformy więziennictwa, red. S. Walczak, Warszawa 1985, s. 53.

6 Nowa encyklopedia powszechna, t. 5, Warszawa 1996, s. 512.

7 H. Machel, Więzienie jako instytucja karna i resocjalizacyjna, dz. cyt., s. 20.

8 Por.: K. Pospiszyl, Resocjalizacja. Teoretyczne podstawy oraz przyktady programów oddziatywań, Warszawa 1998; M. Ciosek, Izolacja więzienna, Gdańsk 1993; O. Lipkowski, Resocjalizacja, Warszawa 1988. 
uprawdopodabnia readaptację społeczną, prowadząc w rezultacie do poczucia osobistego sukcesu, wzmocnienia postaw prospołecznych oraz nabrania dystansu do wcześniejszych doświadczeń ${ }^{9}$. Cel wychowania resocjalizacyjnego to zatem określony krąg modyfikacji, obejmujący nie tylko poprawne funkcjonowanie $\mathrm{w}$ rolach społecznych, ale także, a może głównie, ukształtowanie odpowiednich postaw wobec innych ludzi, norm, wartości i standardów aksjologicznych, a także uznanych za pożądane cech osób wychowywanych, tzn. takich sposobów myślenia, odczuwania i działania, które w świetle ideałów pedagogicznych są uznawane za wartościowe i przez to pożądane jako cele działalności pedagogicznej. Podmiotem działań resocjalizacyjnych jest najogólniej rzecz biorąc jednostka źle przystosowana społecznie, patrząc oczywiście na ów brak przystosowania przez pryzmat ogólnie przyjmowanych systemów wartości czy też norm. W erze ponowoczesności resocjalizację traktuje się więc jako

[...] praktykę rozwiązywania społecznych problemów przestępczości i dewiacji, opartą na metodach oddziaływania na jednostki i grupy, których zachowania przekraczają normy obyczajowe i/lub prawne. Celem jej działań jest modyfikacja tych aspektów sytuacji jednostki, które odpowiadają za możliwość wystąpienia niepożądanych zachowań w przyszłości. Przy czym cel ten realizowany jest na drodze postępowania, którego słuszność daje się uzasadnić w świetle wiedzy wytwarzanej w obrębie nauk szczegółowych, z uwzględnieniem ograniczeń wynikających z konieczności respektowania praw ludzkich odbiorcy wpływu ${ }^{10}$.

\section{Obszary definicyine efektywności}

Z uwagi na wielorakość definicyjną, skuteczności oddziaływań resocjalizacyjnych możemy poszukiwać $\mathrm{w}$ różnych obszarach definicyjnych. Najłatwiej zaobserwować ją w obszarze modyfikacji zachowań. Jest to swego rodzaju wytrenowanie prawidłowych standardów zachowania, często bez trwałych zmian postaw czy przekonań

9 H. Machel, Więzienie jako instytucja karna i resocjalizacyjna, dz. cyt., s. 21.

10 M. Sztuka, Anachronizm i aktualność. Idea resocjalizacji w sporze o nowoczesność, dz. cyt., s. 13. 
resocjalizowanej jednostki. Najprostszą formą oceny skuteczności resocjalizacji penitencjarnej jest niewątpliwie ustalenie wskaźnika recydywy ${ }^{11}$. W literaturze naukowej oraz raportach przedstawiane są bardzo zróżnicowane wskaźniki recydywy, jednak już od kilku lat wahają się one w przedziale 40-50\%. Są one niewątpliwie źródłem cennych informacji o efektach resocjalizacji. W gruncie rzeczy jednak nie wyczerpują wszystkich aspektów stanowiących o rzeczywistych zmianach osobowości, nie wyczerpują zakresu określonych wcześniej celów procesu resocjalizacji. Pedagog, który bezkrytycznie osądza efekty własnej działalności jedynie w oparciu o kryterium recydywy, zdaje się nie rozumieć i nie doceniać istoty wysiłków, jakie podejmuje. Fakt, że osoba resocjalizowana znowu dopuściła się przestępstwa, nie oznacza jeszcze, że nie dokonały się w niej korzystne przeobrażenia. Świadczy natomiast o tym, że zmiany te nie były jeszcze na tyle głębokie, by zagwarantować respektowanie prawa. Nie ma rzecz jasna potrzeby radykalnego przeciwstawiania tych dwóch rodzajów kryteriów efektywności resocjalizacji, z pewnością natomiast należy jednak próbować je łączyć12.

W przypadku resocjalizacji, jako zmiany społecznej przynależności, skuteczność będziemy rozpatrywali w zależności od tego, czy udało się nam wygasić zachowania antyspołeczne bądź brak zainteresowania podkulturą przestępczą, wbudowując w to miejsce pozytywnie realizowane role społeczne lub nawiązanie albo wzmocnienie relacji $\mathrm{z}$ rodziną, wychowawcą, kuratorem. Takie aspekty skuteczności resocjalizacji podkreślają m.in. Kazimierz Pospiszy $1^{13}$, Anetta Jaworska ${ }^{14}$, Aleksandra Szymanowska ${ }^{15}$ czy Franciszek

11 Jako recydywistę określać będziemy przestępcę, który został skazany na karę pozbawienia wolności, odbył co najmniej 6 miesięcy kary i został skazany w ciągu 5 lat za popełnienie przestępstwa podobnego do tego, za które był już uprzednio skazany (art. 64, § 1 i 2 kk).

12 Z. Bartkowicz, Skuteczna resocjalizacja w perspektywie aksjologicznej i pomiarowej, w: Skuteczna resocjalizacja. Doświadczenia i propozycje, red. Z. Bartkowicz, A. Węgliński, Lublin 2008, s. 26.

13 K. Pospiszyl, Plusy i minusy wspótczesnych oddziatywań resocjalizacyjnych, w: Postępy resocjalizacji i profilaktyki spotecznej, red. A. Rejzner, Warszawa 2007, s. 22.

14 A. Jaworska, Leksykon resocjalizacji, Kraków 2012, s. 281-287, 318-367.

15 A. Szymanowska, Więzienie i co dalej, Warszawa 2003, s. 288-304. 
Kozaczuk $^{16}$. Krystyna Ostrowska uwypukla natomiast znaczenie klimatu społecznego instytucji oraz realizowane przez nią cele i zadania wyrażone w konkretnych formach działalności oraz w programach resocjalizacyjnych ${ }^{17}$. Zdaniem Justyny Kusztal ${ }^{18}$, konieczna jest w tym zakresie taka „zmiana optyki”, by środowiska odpowiedzialne za oddziaływania były „widoczne i słyszalne”, bo to właśnie realizatorzy programów resocjalizacyjnych wiedzą najlepiej gdzie brak efektywności lub w jakim zakresie ogranicza ją np. prawo. Zdaniem Roberta Opory, tylko stworzenie odpowiedniej relacji wychowawczej, określenie oczekiwań podopiecznego, ustalenie realistycznych celów, zaplanowanie procesu resocjalizacji i zaangażowanie podopiecznego w realizację zadań oraz właściwy dobór interwencji psychokorekcyjnych pozwoli jednostce niedostosowanej społecznie uzyskać oczekiwane efekty w zakresie readaptacji społecznej ${ }^{19}$.

We wszystkich definicjach resocjalizacji, uszczegóławiających ją między innymi jako przebudowę emocjonalną, wrastanie w kulturę, kształtowanie prawidłowych postaw, reintegrację społeczną czy autoresocjalizację, skuteczność resocjalizacji zawsze umiejscawia się w obszarze społecznego funkcjonowania jednostki. Kazimierz Pospiszyl twierdzi, że dobrym wskaźnikiem skuteczności oddziaływań resocjalizacyjnych może być zmiana w zakresie postaw wobec innych ludzi. Za miernik uzyskanych zmian uznaje on „wyrównanie się postaw społecznych”. Wyrównanie to polega na zmniejszeniu się nadmiernej aktywności i nadmiernej bierności społecznej oraz na obniżeniu się przesadnej propulsywności i przesadnej repulsywności nastawień do innych ludzi ${ }^{20}$. Iwona Niewiadomska podkreśla zwłaszcza rolę motywacji intencjonalnej oraz osobowościowych

16 F. Kozaczuk, Determinanty skutecznej resocjalizacji w opinii skazanych $i$ wychowawców, w: Prawne i socjokulturowe uwarunkowania profilaktyki spotecznej i resocjalizacji, red. F. Kozaczuk, Rzeszów 2009, s. 318-330.

17 K. Ostrowska, Psychologia resocjalizacyjna. W kierunku nowej specjalności zpsychologii, Warszawa 2008.

18 J. Kusztal, Resocjalizacja - readaptacja - reintegracja we wspótczesnym polskim dyskursie naukowym, w: Konteksty resocjalizacji i readaptacji spotecznej, red. J. Kusztal, K. Kmiecik-Jusięga, Kraków 2014, s. 29-31.

19 R. Opora, Kierunki wspótczesnych badań nad efektywnościq oddziatywań resocjalizacyjnych, „Probacja” 2012, nr 3, s. 69-70.

20 Z badań nad postawami rodzicielskimi, red. K. Pospiszyl, Lublin 1988. 
cech wrodzonych ${ }^{21} . Z$ kolei Irena Mudrecka stawia tezę, że sukces resocjalizacji zależy od uświadomienia sobie przez wychowanka konfliktu wewnętrznego, zintelektualizowania własnych motywów działania oraz ich zwerbalizowania ${ }^{22}$. Za cel wychowania resocjalizacyjnego autorka przyjmuje wzmacnianie samokontroli wychowanka ${ }^{23}$ poprzez uczenie go odraczania gratyfikacji, krystalizowanie celów życiowych, uwewnętrznianie obowiązujących standardów, kształtowanie motywacji wewnętrznej czy wreszcie kształtowanie poczucia własnej skuteczności wśród jednostek niedostosowanych społecznie. O trwałości resocjalizacji świadczy również gotowość do pomagania innym ludziom przy zachowaniu własnej indywidualności i wyraźnych oznakach samokreacjii ${ }^{24}$. Zdaniem Jana Szałańskiego, podstawowymi miernikami charakteryzującymi różne wymiary resocjalizacji są: egoizm z pozorami altruizmu (własne korzyści przede wszystkim), altruizm nakazany obowiązującymi normami prawnymi i Dekalogiem, dążenie do najszerszej reintegracji społecznej poprzez współdziałanie i gotowość do pomagania innym ludziom przy zachowaniu własnej indywidualności i wyraźnych oznakach samokreacji oraz trwałość resocjalizacji25. Według Lesława Pytki, efektywność systemu resocjalizacji jest tu uzależniona od użyteczności informacji diagnostycznych na temat systemu sterowanego i jego otoczenia, na które składają się: adekwatność celów działania, a zwłaszcza stopnia ich realności (realizowalności), trafność optymalizowania uwzględniającego współzależność celów, sposobów i środków działania, użyteczności zasileń energetycznych, środków pozostających w dyspozycji systemu sterującego.

21 I. Niewiadomska, Znaczenie podmiotowych predykatorów poprawy moralnej w projektowaniu oddziatywań resocjalizacyjnych wobec osób odbywajacych kary izolacyjne, w: Resocjalizacja: ciagtośc i zmiana, red. M. Konopczyński, B.M. Nowak, Warszawa 2008, s. 130-140.

22 I. Mudrecka, Wykorzystanie konfliktu motywacyjnego w procesie resocjalizacji, $\mathrm{w}$ : Wspótczesne modele i strategie resocjalizacji, red. R. Opora, R. Breska, J. Jezierska, M. Piechowicz, Warszawa 2017, s. 163-164.

23 I. Mudrecka, Wzmacnianie samokontroli jako cel wychowania resocjalizujacego, w: Teoretyczne i metodyczne aspekty resocjalizacji mtodzieży niedostosowanej spotecznie, red. I. Mudrecka, Warszawa 2017, s. 43-54.

24 J. Szałański, Kryteria i mierniki efektywności resocjalizacji, w: Efektywnośc oddziatywań resocjalizacyjnych, red. F. Kozaczuk, Rzeszów 2008, s. 26-27.

25 Tamże, s. 26-27. 
Jak wynika z badań Ewy Wysockiej, należy zatem przypuszczać, że niskie wskaźniki resocjalizacji, z jakimi się spotykamy w praktyce wychowawczej, wiążą się z tzw. „wskaźnikiem zaburzeń”, co jest związane $z$ diagnozą negatywnych konsekwencji funkcjonowania w strukturze instytucji totalnych, $\mathrm{z}$ formami reagowania jednostki na izolację, co z kolei przejawia się np. poprzez samouszkodzenia, tatuaże, zaburzenia psychiczne, wadliwe formy adaptacji, zmiany w osobowości ${ }^{26}$.

\section{Uwarunkowania efektywności oraz jej mierniki}

O ile nie ma wątpliwości co do tego, że proces resocjalizacji winien zmierzać do poprawy społecznego funkcjonowania objętej nim jednostki, to określenie warunków koniecznych i wystarczających do stwierdzenia tej poprawy ukazuje istotne różnice stanowisk. Możliwe odpowiedzi grupują się wokól dwóch centralnych rozstrzygnięć. Zwolennicy pierwszego rozstrzygnięcia uznają prymat, a nawet wyłączność kryterium tzw. poprawy jurydycznej, utrzymując, że najbardziej oczywistym miernikiem skutecznej resocjalizacji jest brak powrotności do przestępstwa. Zaś podstawowy warunek i jednocześnie miernik efektywności podejmowanych działań resocjalizacyjnych stanowi fakt wyeliminowania powrotności do przestępstwa (recydywy) najczęściej szacowanej na podstawie dostępnych statystyk policyjnych i sądowych. Warunkują go najczęściej w kontekście prowadzonych prób badawczych czynniki takie jak: wiek, płeć, rodzaj przestępstwa czy przestępcza historia sprawcy. Natomiast zwolennicy drugiego rozstrzygnięcia ze względu na wciąż niezadowalające efekty podkreślają aktualność ekonomizacji działań resocjalizacyjnych, wyrażającej się w dążeniu do poddania podporządkowanych jej strategii i procedur ogólniejszym zasadom wypracowanym w obrębie teorii zarządzania.

Osiągnięcie założonych efektów resocjalizacyjnych uzależnione jest więc od umiejscowienia podejmowanego działania metodycznego w określonych koncepcjach teoretycznych, rozumianych jako wewnętrznie spójny system pojęć, definicji, twierdzeń, aksjomatów opisanych określoną dziedziną życia społecznego, jako zbiór idei

26 E. Wysocka, Diagnoza w resocjalizacji, Warszawa 2008, s. 298-306. 
lub zasad stosowanych w formie wskazówek do kierowania praktyką, wystarczająco spójnych, aby w razie potrzeby mogły zostać jasno sprecyzowane w formie, która umożliwiałyby dyskusję ${ }^{27}$. Teorie powinny dysponować różnymi perspektywami myślenia, wśród których winna się znaleźć perspektywa ukazująca strukturę i dynamikę zjawiska; perspektywa, która wskaże wszystkie objawy i stadia tego zjawiska oraz perspektywa, która pozwoli prognozować jak to zjawisko będzie się zmieniało $\mathrm{w}$ czasie $^{28}$. W zakresie efektywności podejmowanych wobec jednostek niedostosowanych oddziaływań resocjalizacyjnych $w$ literaturze przedmiotu weryfikowane były już różne koncepcje: biologiczne - koncentrujące się na czynnikach biologicznych w wyjaśnianiu zjawisk przestępczości; psychologiczne - odwołujące się do cech i mechanizmów psychologicznych; socjologiczne, które koncentrowały się na poszukiwaniu przyczyn w mikro- i makrostrukturach społecznych oraz koncepcje eklektyczne, wykorzystujące równocześnie różne konfiguracje wymienionych czynników ${ }^{29}$.

Na współczesną pedagogikę resocjalizacyjną w Polsce najbardziej znaczący wpływ wywarła orientacja humanistyczna, określana też jako postmodernistyczna, weryfikująca założenia resocjalizacji w pytaniu „What works?” („Co działa?”) ${ }^{30}$. Edward J. Latessa i Christopher Lowenkamp, działacze ruchu „What works”, podkreślają, że nie jest on programem czy rodzajem interwencji, ale sumą wiedzy o skutecznych sposobach ograniczania recydywy, zbieranej przez ponad 30 lat badań naukowców głównie z Ameryki Północnej.

27 Ch. Beckett, Podstawy teorii dla praktyków pracy socjalnej, przeł. M. Jasiński, B. Maliszewska, Warszawa 2010, s. 46.

28 P. Sztompka, Teoria i wyjaśnienie: z metodologicznych problemów socjologii, Warszawa 1973.

29 Por.: J.M. Stanik, Wybrane koncepcje i wyniki badań kryminologicznych a perspektywy resocjalizacji, w: Resocjalizacja, t. 1: Teoria i praktyka pedagogiczna, red. B. Urban, J.M. Stanik, Warszawa 2008, s. 116-135; B. Stańdo-Kawecka, Prawne podstawy resocjalizacji, Kraków 2000, s. 15-34.

Por.: B. Stańdo-Kawecka, Ruch What works $i$ „nowa resocjalizacja” - nowa perspektywa w polityce karnej?, w: Węztowe problemy prawa karnego, kryminologii i polityki kryminalnej. Ksiega pamiątkowa ofiarowana Profesorowi Andrzejowi Markowi, red. V. Konarska-Wrzosek, J. Lachowski, J. Wójcikiewicz, Warszawa 2010, s. 901 i nast.; M. Sztuka, Anachronizm czy aktualność. Idea resocjalizacji w sporze o nowoczesność, dz. cyt. 
W warstwie teleologicznej i aksjologicznej badacze ci charakteryzują następująco wychowanie w orientacji humanistycznej: „samourzeczywistnienie wraz $\mathrm{z}$ tendencją do rozwoju potencjału zdolności osobistych" oraz autonomia i wolność podejmowania decyzji, a wraz z nią odpowiedzialność za swoje czyny w relacji z innymi osobami $^{31}$. Kanonem jest tutaj prymat kreacji ${ }^{32}$ i samowychowania ${ }^{33}$ oraz zasada zróżnicowanego traktowania (differential treatment). Pojawiają się również odniesienia do szacowania ryzyka recydywy (koncepcja Risk-Need-Responsivity - RNR) ${ }^{34}$ czy koncepcja resocjalizującego wpływu języka symboli społecznych ${ }^{35}$, określana jako interakcjonizm symboliczny. We współczesnej praktyce resocjalizacyjnej wykorzystywany jest także coraz częściej dorobek pedagogiki społecznej i pracy socjalnej, ale też ekonomii, zwłaszcza przy diagnozie i projektowaniu oddziaływań związanych $\mathrm{z}$ readaptacją, reintegracją społeczną i pomocą postpenitencjarną organizowaną przez organizacje społeczne i instytucje państwowe współdziałające w wykonywaniu kar i środków karnych.

W literaturze przedmiotu mamy do czynienia z rozmaitymi listami czynników warunkujących efektywność resocjalizacyjną. Ich autorzy analizują w ten sposób efektywność resocjalizacji jako osiągnięcie pozytywnych i trwałych rezultatów z punktu widzenia dobra uczestnika tego procesu oraz całego społeczeństwa. Typologie uwarunkowań resocjalizacji przedstawia poniższa tabela.

31 C. Czapów, S. Jedlewski, Pedagogika resocjalizacyjna, dz. cyt., s. 34, 191.

32 Zob. M. Konopczyński, Twórcza resocjalizacja, Warszawa 1996; tenże, Metody twórczej resocjalizacji. Teoria i praktyka wychowawcza, Warszawa 2006; tenże, Kryzys resocjalizacji czy(li) sukces dziatań pozornych. Refleksje wokót polskiej rzeczywistości resocjalizacyjnej, Warszawa 2013.

33 Zob. B. Śliwerski, Teoretyczne i empiryczne podstawy samowychowania, Kraków 2010.

34 Zob.: M. Sztuka, Anachronizm i aktualność. Idea resocjalizacji w sporze o nowoczesność, dz. cyt.; J. Chojecka, Model dla wszystkich? Spory wokót koncepcji szacowania ryzyka recydywy, „Resocjalizacja Polska” 2014, nr 7, s. 85-100.

35 Zob.: A. Siemaszko, Granice tolerancji. O teoriach zachowan dewiacyjnych, Warszawa 1993, s. 265-272; M. Bernasiewicz, Interakcjonizm symboliczny w teorii i praktyce resocjalizacyjnej, Kraków 2011. 
Tabela 1. Typologia czynników i mierników efekływności

\begin{tabular}{|c|c|c|}
\hline Autor & Typologia czynników/determinantów & $\begin{array}{c}\text { Mierniki/wskaźniki } \\
\text { efekływności }\end{array}$ \\
\hline $\begin{array}{l}\text { Kazimierz Pospiszyl } \\
(1998,2007)\end{array}$ & $\begin{array}{l}\text { - Rzetelnie przeprowadzona diagnostyka } \\
\text { osobowości połaczona z dobra znajomościa } \\
\text { ofert profilu oddziaływań resocjalizacyjnych } \\
\text { - Konsekwentne, ale jednocześnie elastyczne } \\
\text { prowadzenie programów resocjalizacyjnych }\end{array}$ & $\begin{array}{l}\text { - „Wyrównanie się postaw } \\
\text { społecznych” }\end{array}$ \\
\hline $\begin{array}{l}\text { Lesław Pytka } \\
(1995,2000)\end{array}$ & $\begin{array}{l}\text { - Diagnoza stanu osobowości wychowanka, } \\
\text { uprzednich wpływów społecznych, a zwłasz- } \\
\text { cza podkulturowych } \\
\text { - Sprawność metodyczna (kwalifikacje i umie- } \\
\text { iętności) kadry pedagogicznej trafnie postu- } \\
\text { lujqqcej cele operacyjne stosownie do treści } \\
\text { rozpoznania diagnostycznego i własnych } \\
\text { możliwości } \\
\text { - Klimat społeczny instytucji resocjalizujqcej, } \\
\text { czyli zbiór parametrów określajqacych jakość } \\
\text { stosunków interpersonalnych w placówce, } \\
\text { stopień autonomii osobistej wychowanków } \\
\text { oraz charakter kontroli sprawowanej przez } \\
\text { kadrę pedagogicznq (np. kontrola } \\
\text { opiekuńcza lub represyjna) }\end{array}$ & $\begin{array}{l}\text { - Wywiqzywanie się z funkcji } \\
\text { formatywnej, sprawozdaw- } \\
\text { czo-selekcjonujqcei, } \\
\text { psychologicznej, administra- } \\
\text { cyjnej, edukacyjnej }\end{array}$ \\
\hline $\begin{array}{l}\text { Bronisław Urban } \\
(2008)\end{array}$ & $\begin{array}{l}\text { - Brak powrotności do przestępstwa, ale } \\
\text { również zhierarchizowany system wartości } \\
\text { uniwersalnych } \\
\text { - Rozwinięty system kontroli wewnętrznej } \\
\text { - Pozytywna i realna samoocena }\end{array}$ & $\begin{array}{l}\text { - Wskaźnik recydywy } \\
\text { - Pozytywne przemiany w sfe- } \\
\text { rze motywacyinej, kontrolnej } \\
\text { - Efektywne uczestnictwo } \\
\text { w życiu społecznym w społe- } \\
\text { czeństwie wolnościowym }\end{array}$ \\
\hline $\begin{array}{l}\text { Zdzisław Bartkowicz } \\
(2008)\end{array}$ & $\begin{array}{l}\text { - Brak powrotności do przestępstwa } \\
\text { - Zmiany w zakresie osobowości i zachowania }\end{array}$ & $\begin{array}{l}\text { - Kryteria jurydyczne } \\
\text { - Kryteria natury psychope- } \\
\text { dagogicznej }\end{array}$ \\
\hline $\begin{array}{l}\text { Ewa Wysocka } \\
(2008)\end{array}$ & $\begin{array}{l}\text { - Brak powrotności do przestępstwa } \\
\text { - Różnice między stanem wyjściowym i koń- } \\
\text { cowym w procesie modyfikacji osobowości } \\
\text { skazanego, a zwłaszcza jej cech, prezentowa- } \\
\text { nych postaw społecznych, nastawień wobec } \\
\text { innych oraz własnej osoby, wobec powszech- } \\
\text { nie uznanych norm i wartości, czyli umiejętności } \\
\text { współżycia z ludźmi w zgodzie ze sobq ale } \\
\text { też czynników makrospołecznych } \\
\text { - Formy reagowania jednostki na izolacię } \\
\text { (wadliwe formy adaptacii, zmiany } \\
\text { w osobowości, patologie grupy osadzonych } \\
\text { i zakładu karnego jako instyłucii) }\end{array}$ & $\begin{array}{l}\text { - „Wskaźnik recydywy” } \\
\text { - „Wskaźnik zmian” dokonu- } \\
\text { iqqcych się w jednostce i jei } \\
\text { otoczeniu } \\
\text { - „Wskaźnik zaburzeń” } \\
\text { zwiqzany z diagnozq } \\
\text { negatywnych konsekwencji } \\
\text { funkcjonowania w strukturze } \\
\text { instytucii totalnych }\end{array}$ \\
\hline
\end{tabular}




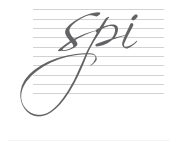

\begin{tabular}{|c|c|c|}
\hline Autor & Typologia czynników/determinantów & $\begin{array}{c}\text { Mierniki/wskaźniki } \\
\text { efektywności }\end{array}$ \\
\hline $\begin{array}{l}\text { Jan Szałański } \\
(2008)\end{array}$ & $\begin{array}{l}\text { - Przeżywanie uczuć wyższych, } \\
\text { zwłaszcza empatii } \\
\text { - Chęć niesienia pomocy innym } \\
\text { - Zdolności do abstrakcyjnego myślenia } \\
\text { i przeżywania poczucia winy } \\
\text { - Zaakceptowanie przez skazanego etycznego } \\
\text { wymiaru winy i kary jako odpowiedzialności } \\
\text { za popełniony czyn } \\
\text { - Zinternalizowanie obowiqzujacych norm } \\
\text { oraz uruchomienie wewnętrznej kontroli } \\
\text { i autowzmacniania swojego zachowania } \\
\text { - Własne „doczłowieczanie” rozumiane jako } \\
\text { „świadome i intencionalne kreowanie siebie”, } \\
\text { autonomiczne dqzżenie do harmonijnej } \\
\text { reintegracii społecznej }\end{array}$ & $\begin{array}{l}\text { - Egoizm z pozorami altruizmı } \\
\text { (własne korzyści przede } \\
\text { wszystkim) } \\
\text { - Altruizm nakazany } \\
\text { obowiqzującymi normami } \\
\text { prawnymi i Dekalogiem } \\
\text { - Dażenie do najszerszej } \\
\text { reintegracji społecznej } \\
\text { poprzez współdziałanie } \\
\text { i gotowość do pomagania } \\
\text { innym ludziom przy } \\
\text { zachowaniu własnej } \\
\text { indywidualności i wyraźnych } \\
\text { oznakach samokreacji }\end{array}$ \\
\hline $\begin{array}{l}\text { Iwona } \\
\text { Niewiadomska } \\
\text { (2008) }\end{array}$ & $\begin{array}{l}\text { - Osobowościowe cechy wrodzone, ti. } \\
\text { sumienność } \\
\text { - Względnie stałe kognitywne wymiary } \\
\text { osobowości } \\
\text { - Odpowiedzialność za wzmacnianie } \\
\text { motywacii intencjonalnei (kryzys } \\
\text { wartościowania, poczucie koherencji) } \\
\text { - Doświadczanie dystansu społecznego } \\
\text { (poczucie oceny społecznei) } \\
\text { - Przeżywanie stresu (spostrzeganie syłuacji } \\
\text { trudnych) } \\
\text { - Zasoby odpornościowe w radzeniu sobie } \\
\text { z występujqcymi problemami (poczucie } \\
\text { koherencii, doświadczenie wsparcia } \\
\text { społecznego) }\end{array}$ & $\begin{array}{l}\text { - Organizacja życia } \\
\text { osobistego } \\
\text { - Określenie i realizacja } \\
\text { bliższych i dalszych celów } \\
\text { życiowych } \\
\text { - Wytrwałość w poszukiwaniu } \\
\text { i wykonywaniu pracy } \\
\text { - Nawiqzanie pozytywnych } \\
\text { kontaktów interpersonalnych } \\
\text { - Stabilność życia rodzinnego }\end{array}$ \\
\hline $\begin{array}{l}\text { Franciszek Kozaczuk } \\
\text { (2009) }\end{array}$ & $\begin{array}{l}\text { - Wsparcie rodziny } \\
\text { - Możliwość zatrudnienia na wolności } \\
\text { - Poczucie odpowiedzialności } \\
\text { - Silny charakter } \\
\text { - Przestrzeganie przepisów prawnych } \\
\text { - Zerwanie z „marginesem społecznym” } \\
\text { Niżei plasuja się: umiejętność przystosowania } \\
\text { do warunków wolnościowych, założenie } \\
\text { rodziny, brak nałogów, wsparcie przyjaciół czy } \\
\text { przygotowanie zawodowe }\end{array}$ & $\begin{array}{l}\text { - Organizacja życia } \\
\text { osobistego } \\
\text { - Praca } \\
\text { - „Wskaźnik recydywy” } \\
\text { - Nawiqzanie pozytywnych } \\
\text { kontaktów interpersonalnych }\end{array}$ \\
\hline
\end{tabular}




\begin{tabular}{|c|c|c|}
\hline Autor & Typologia czynników/determinantów & $\begin{array}{c}\text { Mierniki/wskaźniki } \\
\text { efektywności }\end{array}$ \\
\hline $\begin{array}{l}\text { Aleksandra } \\
\text { Szymanowska } \\
(2007)\end{array}$ & $\begin{array}{l}\text { - Brak zainteresowania podkultura przestępcza } \\
\text { - Chęć poprawy } \\
\text { - Dobry stan zdrowia } \\
\text { - Posiadane kwalifikacje zawodowe } \\
\text { - Niekaralność w okresie nieletniości } \\
\text { - Wsparcie rodziny }\end{array}$ & $\begin{array}{l}\text { - Wypełnianie powierzonych } \\
\text { ról społecznych } \\
\text { - Bycie aktywnym członkiem } \\
\text { społeczności lokalnej }\end{array}$ \\
\hline $\begin{array}{l}\text { Anetta Jaworska } \\
(2008,2012)\end{array}$ & $\begin{array}{l}\text { - Zmiana wizerunku skazanych w odbiorze } \\
\text { społecznym } \\
\text { - Motywacja i gotowość do przemiany życia } \\
\text { i zgodnego z prawem funkcjonowania } \\
\text { w społeczeństwie } \\
\text { - Promowanie szeroko poiętei zmiany } \\
\text { przestępcy } \\
\text { - Wykształcenie się pozyływnych interakcji } \\
\text { między wychowawcq, kuratorem } \\
\text { a podopiecznym }\end{array}$ & $\begin{array}{l}\text { - Uzyskanie przez skazanego } \\
\text { osobistego zadowolenia } \\
\text { z życia i pełnej jego } \\
\text { akceptacji } \\
\text { - Nowy stosunek do } \\
\text { otaczajqcej rzeczywistości } \\
\text { społecznej }\end{array}$ \\
\hline $\begin{array}{l}\text { Robert Opora } \\
(2012)\end{array}$ & $\begin{array}{l}\text { - Brak powrotności do przestępstwa } \\
\text { - Ściśle określone kryteria udziału w projekcie } \\
\text { - Zróżnicowanie pomocy } \\
\text { - Motywowanie skazanego do dokonania } \\
\text { zmiany } \\
\text { - Stworzenie odpowiedniej relacji } \\
\text { wychowawczej } \\
\text { - Dopasowanie treści struktury programu do } \\
\text { stylu uczenia się skazanego } \\
\text { - Dobrze wyposażony i przygotowany } \\
\text { personel } \\
\text { - Koncentracja na czynnikach będaqcych } \\
\text { podstawq przestępczości, ti. postawy } \\
\text { antyspołeczne, uzależnienie, deficyty } \\
\text { w obszarze umiejętności społecznych } \\
\text { - Konsekwencja w stosowaniu interwencji } \\
\text { przez personel (ilość, kolejność, jakość } \\
\text { podejmowanych interwencji) }\end{array}$ & $\begin{array}{l}\text { - „Wskaźnik recydywy” } \\
\text { - Podjęte oddziaływania } \\
\text { pojednawcze } \\
\text { - Poprawa umiejętności } \\
\text { społecznych, a w efekcie } \\
\text { zdobycie zatrudnienia } \\
\text { i utrzymanie podiętej pracy } \\
\text { - Podtrzymywanie } \\
\text { pozytywnych relacii } \\
\text { społecznych } \\
\text { - Wnoszenie wkładu w życie } \\
\text { społeczeństwa }\end{array}$ \\
\hline
\end{tabular}




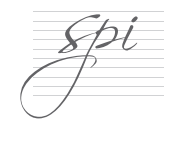

\begin{tabular}{|c|c|c|c|}
\hline Autor & \multicolumn{2}{|c|}{ Typologia czynników/determinantów } & $\begin{array}{l}\text { Mierniki/wskaźniki } \\
\text { efektywności }\end{array}$ \\
\hline \multirow[t]{4}{*}{$\begin{array}{l}\text { Anna Fidelus } \\
(2012)\end{array}$} & $\begin{array}{c}\text { Czynniki zewnętrzne } \\
\text { (egzogenne) }\end{array}$ & $\begin{array}{c}\text { Czynniki wewnętrzne } \\
\text { (endogenne) }\end{array}$ & \multirow{4}{*}{$\begin{array}{l}\text { - Brak zachowań charaktery- } \\
\text { zujących się różnego typu } \\
\text { wykroczeniami w zakresie } \\
\text { normy społecznej, moralnej } \\
\text { oraz prawnej } \\
\text { - Podjęcie aktywności zawo- } \\
\text { dowej } \\
\text { - Dobre relacje z członkami } \\
\text { rodziny } \\
\text { - Dobre relacje ze społecznoś- } \\
\text { ciq̨ lokalnq } \\
\text { - Brak uzależnień } \\
\text { - Samoprzekonanie skazane- } \\
\text { go o pomyślnym przebiegu } \\
\text { readaptacji społecznej }\end{array}$} \\
\hline & $\begin{array}{l}\text { - Czynniki sytuacyjne } \\
\text { (kryzysy, trudności, } \\
\text { subiektywne od- } \\
\text { czuwanie sytuacii } \\
\text { trudnych) }\end{array}$ & $\begin{array}{l}\text { - Czynniki biologiczne } \\
\text { (temperament, typ } \\
\text { układu nerwowego) }\end{array}$ & \\
\hline & $\begin{array}{l}\text { - Czynniki społeczne } \\
\text { i kulturowe } \\
\text { (doświadczenia } \\
\text { wczesnodziecięce, } \\
\text { styl wychowania } \\
\text { w rodzinie, postawy, } \\
\text { warunki byłowe, za- } \\
\text { sady postępowania, } \\
\text { normy, role podejmo- } \\
\text { wane w rodzinie, sieci } \\
\text { wsparcia, szeroko } \\
\text { poięta kultura ma- } \\
\text { sowa) }\end{array}$ & $\begin{array}{l}\text { - Czynniki osobowoś- } \\
\text { ciowe } \\
\text { (poziom optymizmu } \\
\text { lub pesymizmu, po- } \\
\text { ziom satysfakcii z ży- } \\
\text { cia i siebie samego, } \\
\text { rozbieżność pomiędzy } \\
\text { Ja idealnym a Ja } \\
\text { realnym, poszukiwanie } \\
\text { tożsamości, rywaliza- } \\
\text { cja, potrzeby i aspi- } \\
\text { racje, lęki, odporność } \\
\text { psychofizyczna } \\
\text { organizmu) }\end{array}$ & \\
\hline & \multicolumn{2}{|c|}{$\begin{array}{l}\text { Ponadto: stan zdrowia, wiek, płeć, sprawność } \\
\text { intelekłualna, inteligencja, odpowiedzialność, } \\
\text { spolegliwość, przynależność do określonych } \\
\text { grup społecznych, wrażliwość na potrzeby } \\
\text { innych ludzi, dobro społeczne }\end{array}$} & \\
\hline \multirow[t]{2}{*}{$\begin{array}{l}\text { Marek Heine } \\
(2013)\end{array}$} & $\begin{array}{c}\text { Czynniki w skali } \\
\text { mikro }\end{array}$ & $\begin{array}{l}\text { Czynniki w skali } \\
\text { makro }\end{array}$ & \multirow{2}{*}{$\begin{array}{l}\text { - Brak zachowań charaktery- } \\
\text { zujacych się różnego typu } \\
\text { wykroczeniami w zakresie } \\
\text { normy społecznej, moralnei } \\
\text { oraz prawnej } \\
\text { - Wnoszenie wkładu w życie } \\
\text { społeczeństwa } \\
\text { - Podtrzymywanie pozytyw- } \\
\text { nych relacii społecznych }\end{array}$} \\
\hline & $\begin{array}{l}\text { - Adekwatność sto- } \\
\text { sowanych metod } \\
\text { i technik } \\
\text { - Umiejętności osób } \\
\text { kierujących proce- } \\
\text { sem resocjalizacji } \\
\text { - Środki materialne } \\
\text { zabezpieczajace } \\
\text { możliwość osiag- } \\
\text { nięcia celu } \\
\text { - Postawy osób } \\
\text { objętych resocja- } \\
\text { lizacja w stosunku } \\
\text { do zastosowanych } \\
\text { środków }\end{array}$ & $\begin{array}{l}\text { - Polityka kryminalna } \\
\text { państwa } \\
\text { - Stosunek społeczeń- } \\
\text { stwa do przestęp- } \\
\text { stwa, przestępcy } \\
\text { i kary } \\
\text { - Funkcjonowanie } \\
\text { organów ochrony } \\
\text { prawnej }\end{array}$ & \\
\hline
\end{tabular}

Źródło: opracowanie własne na podstawie dostępnej literatury. 
Wielość i odmienność stanowisk nie ułatwia z jednej strony pełnego zrozumienia funkcjonowania człowieka, $\mathrm{z}$ drugiej strony jednak mobilizuje do nieustannego poszukiwania wyjaśnień złożoności ludzkiej natury. Powstrzymanie się od powrotnej przestępczości nie zawsze jest wynikiem kontroli jednostki czy też świadomej i konsekwentnej zmiany stylu życia lub postaw. Może ono być bowiem incydentalnym zbiegiem korzystnych $\mathrm{z}$ resocjalizacyjnego punktu widzenia okoliczności powstrzymujących jednostkę przed zachowaniem naruszającym normy prawne.

Brak recydywy to jedynie wskaźnik behawioralny, jak pisze Bronisław Urban, nie zawsze pokrywający się z osobowościowymi wyznacznikami zachowania ocenianego przez system aksjonormatywny. $\mathrm{Z}$ tego właśnie względu $\mathrm{z}$ pedagogicznego punktu widzenia brak recydywy nie stanowi i nie może stanowić pełnego kryterium efektywności resocjalizacji. Pełna resocjalizacja ujmowana w standardach aksjonormatywnych winna, zdaniem Urbana, być złożona ze zhierarchizowanego systemu wartości uniwersalnych, rozwiniętego systemu kontroli wewnętrznej oraz pozytywnej i realnej samooceny. Dopiero wówczas gwarantować może ona stopień przystosowania się do realnych warunków społecznych. Zaś „kryterium efektywności oddziaływań resocjalizacyjnych powinien być nie tylko brak powrotności do przestępstwa, ale również pozytywne przemiany w sferze motywacyjnej, kontrolnej oraz efektywne uczestnictwo w życiu społecznym w społeczeństwie wolnościowym"36.

\section{Podsumowanie}

W perspektywie zachodzących pod wpływem humanistyki zmian podejmowane działania resocjalizacyjne splatają się współcześnie we wspólny nurt o komplementarnym, holistycznym charakterze. Właśnie w tym holistycznym podejściu ${ }^{37}$ uwidacznia się najlepiej tożsamość pedagogiki resocjalizacyjnej jako dyscypliny w ujęciu

B. Urban, Ocena rezultatów resocjalizacji,w: Resocjalizacja, t. 1: Teoria i praktyka pedagogiczna, red. J.M. Stanik, B. Urban, Warszawa 2008, s. 313-317.

37 Zob. K. Duraj-Nowakowa, Źródta podejsé pedagogiki. Zarys problemów, Kielce 2005, s. 196-204. 
teoretycznym i praktycznym ${ }^{38} \mathrm{z}$ bogatym wachlarzem warunkujących jej efektywność czynników. Resocjalizacja jest zatem

[...] wiedzą i dyscypliną naukową, a wynikające z niej umiejętności i techniki służą rozwojowi intencjonalnych procesów oddziaływań na człowieka, których celem jest zmiana jego postaw społecznych, ocenianych jako wadliwe, na zgodne z ogólnymi normami życia społecznego, a w szczególności normami prawa karnego, czyli korekta pod tym względem wcześniejszego procesu socjalizacji39.

Resocjalizacja jako proces interaktywny zachodzi więc w zakresie prawidłowych reakcji społecznych na określone zachowania problemowe. Bez rehabilitacji społecznej podmiotów oddziaływań resocjalizacyjnych nie będzie ona społecznie efektywna także jako skuteczny środek kontroli społecznej ${ }^{40}$.

Należy więc weryfikować dokonujące się w następstwie resocjalizacji zmiany przez pryzmat szerokiej puli czynników. Przykładem takiej analizy są badania Anny Fidelus. Autorka weryfikuje determinanty zmiany w dwu wzajemnie warunkujących się układach, dzieląc je na czynniki zewnętrzne (egzogenne) i wewnętrzne (endogenne). W czynnikach egzogennych zawierają się determinanty efektywności strategii adaptacyjnych jednostki. Są to czynniki sytuacyjne (kryzysy, trudności, subiektywne odczuwanie sytuacji trudnych) oraz społeczne i kulturowe (doświadczenia wczesnodziecięce, styl wychowania w rodzinie, zasady postępowania, normy, sieci wsparcia, szeroko pojęta kultura masowa). Wśród czynników endogennych znajdują się czynniki biologiczne, takie jak temperament, system nerwowy, osobowość, poziom optymizmu lub pesymizmu, satysfakcja z życia i siebie samego, rozbieżność pomiędzy Ja idealnym a Ja realnym, tożsamość, rywalizacja, potrzeby i aspiracje, lęki, odporność psychofizyczna organizmu. Do czynników tych należy także stan zdrowia, wiek, płeć, sprawność intelektualna. Ważną rolę odgrywa też inteligencja, odpowiedzialność, spolegliwość, przynależność do określonych grup

38 P. Szczepaniak, Kierunki rozwoju pedagogiki penitencjarnej, w: Postępy resocjalizacji i profilaktyki spotecznej, red. A. Rejzner, Warszawa 2007, s. 49.

39 J. Utrat-Milecki, Resocjalizacja, w: Socjologia prawa. Gtówne problemy i postacie, red. A. Kojder, Z. Cywiński, Warszawa 2014, s. 400-403.

40 J. Utrat-Milecki, Aktualność programu profilaktyki spotecznej i resocjalizacji na Uniwersytecie Warszawskim, „Profilaktyka Społeczna i Resocjalizacja” 2015, t. 25 , s. $163-179$. 
społecznych, wrażliwość na potrzeby innych ludzi, dobro społeczne ${ }^{41}$. W badaniach własnych autorka weryfikuje jako wskaźniki pozytywnej readaptacji: brak zachowań charakteryzujących się różnego typu wykroczeniami w zakresie normy społecznej, moralnej oraz prawnej; podjęcie aktywności zawodowej; dobre relacje z członkami rodziny; dobre relacje ze społecznością lokalną; brak uzależnień oraz samoprzekonanie skazanego o pomyślnym przebiegu readaptacji społecznej. Występowanie co najmniej trzech z powyższych wskaźników przez sześć miesięcy świadczy, zdaniem Anny Fidelus, „o pozytywnych tendencjach w procesie readaptacji społecznej"42.

Marek Heine ujmuje efektywność resocjalizacji także bardzo kompleksowo, grupując efekty na indywidualne i systemowe. Jego zdaniem, czynniki wpływające na efektywność resocjalizacji można umownie podzielić na czynniki działające w mikro- i makroskali. Do czynników w skali mikro autor zalicza: adekwatność stosowanych metod i technik, umiejętności osób kierujących procesem, środki materialne zabezpieczające możliwość osiągnięcia celu oraz postawy osób objętych resocjalizacją w stosunku do zastosowanych wobec nich środków. Natomiast do czynników występujących w skali makro zalicza: politykę kryminalną państwa, stosunek społeczeństwa do przestępstwa, przestępcy i kary, funkcjonowanie organów ochrony prawnej ${ }^{43}$. Zdaniem autora, ich skuteczność zależy od poziomu niedostosowania społecznego jednostki, woli podjęcia przez nią wysiłków celem zmiany, współpracy z pedagogiem resocjalizacyjnym, od jakości z nim kontaktów i jego kompetencji. Kryterium umożliwiające ocenę efektywności tak podjętych działań wymaga zastosowania narzędzi diagnozy psychologicznej, socjologicznej i pedagogicznej oraz odpowiedniego po odbyciu kary czasu, by dokonać rzetelnych wnioskowań. Są to kryteria określane jako „socjopedagogiczne”, ponieważ dają szansę na dostrzeżenie zmian zachodzących w resocjalizowanych jednostkach nawet wówczas, gdy one same sobie tego

41 A. Fidelus, Determinanty readaptacji spotecznej skazanych, Warszawa 2012, s. $46-57$.

42 Tamże, s. 233-234.

43 M. Heine, Efektywność resocjalizacji - kontrowersje wokót znaczenia pojęcia, w: Profilaktyka spoteczna i resocjalizacja w nurtach inkluzji. Doświadczenia, problemy, perspektywy międzynarodowe, red. B. Jezierska, A. Rejzner, P. Szczepanik, A. Szecówka, Warszawa 2013, s. 158-161. 
nie uświadamiają, a nawet wypierają ich istnienie. Osoby objęte resocjalizacją $\mathrm{w}$ izolacji od środowiska naturalnego nie potrafią $\mathrm{w}$ pełni aktywnie odpowiadać na oferowane formy pomocy. Często wręcz manifestują wrogość wobec tego, kto taką ofertę prezentuje. Dlatego też drugim istotnym kryterium jest czas po opuszczeniu jednostki penitencjarnej, który ostatecznie weryfikuje efektywność resocjalizacji. Nie oznacza to jednak, że podjęte działania wychowawcze, pomocowe czy terapeutyczne pozostaną niezauważone, a postawy i wzorce zachowania prezentowane przez wychowawców nie wywołają „mikronastępstw”.

Efektywna resocjalizacja to „optymalna homeostaza społeczna”, która ma zmierzać do twórczej samorealizacji1 jednostki, co dokonuje się zwłaszcza poprzez przeżywanie uczuć wyższych, szczególnie empatii, chęci niesienia pomocy innym, zdolności do abstrakcyjnego myślenia i przeżywania poczucia winy, świadome intencjonalne kreowanie siebie, autonomiczne dążenie do harmonijnej reintegracji społecznej. Miarą skuteczności jest więc stopień zbliżenia się do celu, który został założony. Minimalna i przewidywana skuteczność musi być na tyle duża, aby można było osiągnąć pewność, że warto podjąć działanie, dlatego też konieczne jest skupienie się na zindywidualizowanych i wielowymiarowych działaniach podejmowanych $\mathrm{w}$ kontekście instytucjonalnym, społecznym oraz indywidualnym. Katalog mierników efektywności powinien być taki, by pozwolił na dokonanie ocen wartościujących i monitorowanie programów oddziaływań resocjalizacyjnych, warunków i środków ich prowadzenia, zmian dokonujących się w środowisku życia osoby resocjalizowanej oraz zjawisk patologicznych obecnych w jej otoczeniu.

\section{Bibliografia}

Bartkowicz Z., Skuteczna resocjalizacja w perspektywie aksjologicznej i pomiarowej, w: Skuteczna resocjalizacja. Doświadczenia i propozycje, red. Z. Bartkowicz, A. Węgliński, Wydawnictwo UMCS, Lublin 2008, s. 23-28.

44 J. Szałański, Kategorie klasyfikacyjne i zróżnicowanie osobowościowe skazanych jako wyznaczniki celów i programów resocjalizacji penitencjarnej, w: Resocjalizacja, t. 1: Teoria i praktyka pedagogiczna, red. J.M. Stanik, B. Urban, Warszawa 2008, s. 375 i nast. 
Beckett Ch., Podstawy teorii dla praktyków pracy socjalnej, przeł. M. Jasiński, B. Maliszewska, Wydawnictwo Akademii Pedagogiki Specjalnej, Warszawa 2010.

Bernasiewicz M., Interakcjonizm symboliczny w teorii i praktyce resocjalizacyjnej, Oficyna Wydawnicza „Impuls”, Kraków 2011.

Chojecka J., Model dla wszystkich? Spory wokót koncepcji szacowania ryzyka recydywy, „Resocjalizacja Polska” 2014, nr 7, s. 85-100.

Ciosek M., Izolacja więzienna, Wydawnictwo Uniwersytetu Gdańskiego, Gdańsk 1993.

Czapów C., Jedlewski S., Pedagogika resocjalizacyjna, PWN, Warszawa 1971.

Duraj-Nowakowa K., Źródta podejść pedagogiki. Zarys problemów, Świętokrzyska Szkoła Wyższa, Kielce 2005.

Fidelus A., Determinanty readaptacji spotecznej skazanych, Wydawnictwo UKSW, Warszawa 2012.

Heine M., Efektywność resocjalizacji - kontrowersje wokót znaczenia pojęcia, w: Profilaktyka spoteczna i resocjalizacja w nurtach inkluzji. Doświadczenia, problemy, perspektywy międzynarodowe, red. B. Jezierska, A. Rejzner, P. Szczepanik, A. Szecówka, Wydawnictwo UW, Instytut Profilaktyki Społecznej i Resocjalizacji, Warszawa 2013, s. 156-165.

Jaworska A., Leksykon resocjalizacji, Oficyna Wydawnicza „Impuls”, Kraków 2012.

Konopczyński M., Kryzys resocjalizacji czy(li) sukces dziatań pozornych. ReAleksje wokót polskiej rzeczywistości resocjalizacyjnej, Pedagogium Wyższa Szkoła Nauk Społecznych, Warszawa 2013.

Konopczyński M., Metody twórczej resocjalizacji. Teoria i praktyka wychowawcza, Wydawnictwo Naukowe PWN, Warszawa 2006.

Konopczyński M., Twórcza resocjalizacja, MEN, Editions Spotkania, Warszawa 1996.

Kozaczuk F., Determinanty skutecznej resocjalizacji w opinii skazanych $i$ wychowawców, w: Prawne i socjokulturowe uwarunkowania profilaktyki spotecznej $i$ resocjalizacji, red. F. Kozaczuk, Wydawnictwo Uniwersytetu Rzeszowskiego, Rzeszów 2009, s. 318-330.

Kusztal J., Resocjalizacja - readaptacja - reintegracja we wspótczesnym polskim dyskursie naukowym, w: Konteksty resocjalizacji i readaptacji spotecznej, red. J. Kusztal, K. Kmiecik-Jusięga, Akademia Ignatianum w Krakowie, Wydawnictwo WAM, Kraków 2014, s. 25-43.

Lipkowski O., Resocjalizacja, Wydawnictwa Szkolne i Pedagogiczne, Warszawa 1988.

Machel H., Więzienie jako instytucja karna i resocjalizacyjna, Arche, Gdańsk 2003.

Mudrecka I., Wykorzystanie konfliktu motywacyjnego w procesie resocjalizacji, w: Wspótczesne modele i strategie resocjalizacji, red. R. Opora, R. Breska, J. Jezierska, M. Piechowicz, Difin, Warszawa 2017, s. 161-180.

Mudrecka I., Wzmacnianie samokontroli jako cel wychowania resocjalizujacego, w: Teoretyczne i metodyczne aspekty resocjalizacji mtodzieży niedostosowanej 
spotecznie, red. I. Mudrecka, Wydawnictwo Pedagogium Wyższej Szkoły Pedagogiki Resocjalizacyjnej, Warszawa 2017, s. 43-56.

Niewiadomska I., Znaczenie podmiotowych predykatorów poprawy moralnej w projektowaniu oddziatywań resocjalizacyjnych wobec osób odbywajacych kary izolacyjne, w: Resocjalizacja: ciagtość i zmiana, red. M. Konopczyński, B.M. Nowak, Wydawnictwo Pedagogium Wyższej Szkoły Pedagogiki Resocjalizacyjnej, Warszawa 2008, s. 130-140.

Nowa encyklopedia powszechna, t. 5, Wydawnictwo Naukowe PWN, Warszawa 1996.

Opora R., Kierunki wspótczesnych badań nad efektywnościq oddziatywań resocjalizacyjnych, „Probacja” 2012, nr 3, s. 67-81.

Ostrowska K., Psychologia resocjalizacyjna. $W$ kierunku norvej specjalności z psychologii, Fraszka Edukacyjna, Warszawa 2008.

Pospiszyl K., Plusy i minusy wspótczesnych oddziatywań resocjalizacyjnych, w: Postępy resocjalizacji i profilaktyki spotecznej, red. A. Rejzner, Instytut Profilaktyki Społecznej i Resocjalizacji UW, Warszawa 2007, s. 21-25.

Pospiszyl K., Resocjalizacja nieletnich. Doświadczenia i koncepcje, Wydawnictwa Szkolne i Pedagogiczne, Warszawa 1990.

Pospiszyl K., Resocjalizacja. Teoretyczne podstawy oraz przykłady programów oddziatywań, Wydawnictwo Akademickie „Żak”, Warszawa 1998.

Siemaszko A., Granice tolerancji. O teoriach zachowan dewiacyjnych, Wydawnictwo Naukowe PWN, Warszawa 1993.

Stanik J.M., Wybrane koncepcje i wyniki badań kryminologicznych a perspektywy resocjalizacji, w: Resocjalizacja, t. 1: Teoria i praktyka pedagogiczna, red. B. Urban, J.M. Stanik, Wydawnictwo Naukowe PWN, Warszawa 2008 , s. 116-135.

Stańdo-Kawecka B., Prawne podstawy resocjalizacji, Zakamycze, Kraków 2000.

Stańdo-Kawecka B., Ruch What works i „nowa resocjalizacja” - nowa perspektywa w polityce karnej?, w: Węztowe problemy prawa karnego, kryminologii i polityki kryminalnej. Ksiegga pamiatkowa ofiarowana Profesorowi Andrzejowi Markowi, red. V. Konarska-Wrzosek,J. Lachowski, J. Wójcikiewicz, Wolters Kluwer, Warszawa 2010, s. 891-907.

Szałański J., Kategorie klasyfikacyjne i zróżnicowanie osobowościowe skazanych jako wyznaczniki celów i programórw resocjalizacji penitencjarnej, w: Resocjalizacja, t. 1: Teoria i praktyka pedagogiczna, red. B. Urban,J.M. Stanik, Wydawnictwo Naukowe PWN, Warszawa 2008, s. 361-396.

Szałański J., Kryteria i mierniki efektywności resocjalizacji, w: Efektywnośc oddziatywań resocjalizacyjnych, red. F. Kozaczuk, Wydawnictwo Uniwersytetu Rzeszowskiego, Rzeszów 2008, s. 21-28.

Szczepaniak P., Kierunki rozwoju pedagogiki penitencjarnej, w: Postępy resocjalizacji i profilaktyki spotecznej, red. A. Rejzner, Wydawnictwo UW, Warszawa 2007 , s. 37-57.

Sztompka P., Teoria i wyjaśnienie: z metodologicznych problemów socjologii, PWN, Warszawa 1973. 
Sztuka M., Anachronizm i aktualność. Idea resocjalizacji w sporze o nowoczesność, Wydawnictwo UJ, Kraków 2013.

Szymanowska A., Więzienie i co dalej, Wydawnictwo Akademickie "Żak”, Warszawa 2003.

Śliwerski B., Teoretyczne i empiryczne podstawy samowychowania, Oficyna Wydawnicza „Impuls”, Kraków 2010.

Urban B., Ocena rezultatów resocjalizacji, w: Resocjalizacja, t. 1: Teoria i praktyka pedagogiczna, red. J.M. Stanik, B. Urban, Wydawnictwo Naukowe PWN, Warszawa 2008, s. 312-317.

Utrat-Milecki J., Aktualność programu profilaktyki spotecznej i resocjalizacji na Uniwersytecie Warszawskim, „Profilaktyka Społeczna i Resocjalizacja” 2015, t. 25, s. 163-179.

Utrat-Milecki J., Resocjalizacja, w: Socjologia prawa. Gtówne problemy i postacie, red. A. Kojder, Z. Cywiński, Wydawnictwo UW, Warszawa 2014, s. 400-403.

Waligóra B., Warunki i instrumenty resocjalizacji osób pozbawionych wolności, w: Spory wokót reformy więziennictwa, red. S. Walczak, Instytut Profilaktyki Społecznej i Resocjalizacji UW, Warszawa 1985, s. 50-64.

Wysocka E., Diagnoza w resocjalizacji, Wydawnictwo Naukowe PWN, Warszawa 2008.

Z badań nad postawami rodzicielskimi, red. K. Pospiszyl, UMCS, Lublin 1988.

\section{ADRES DO KORESPONDENCJI:}

\section{mgr Joanna Sztuka}

Akademia Ignatianum w Krakowie

Instytut Nauk o Wychowaniu

e-mail: joanna.sztuka@ignatianum.edu.pl 